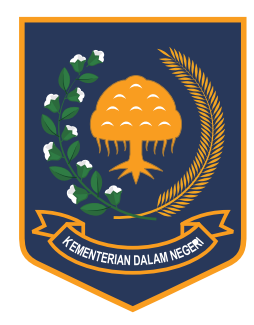

\title{
IMPROVEMENT OF RESEARCHER'S PERFORMANCE THROUGH EMPOWERMENT, ORGANIZATION COMMITMENT AND INNOVATION IN THE Ministry OF Home AFFAIRS AND REgIONAL GOVERnMENT
}

\author{
Teguh Narutomo*, Muchlis R. Luddin, Thomas Suyatno \\ Universitas Negeri Jakarta \\ Jl. Rawamangun Muka, Jakarta, 13220, Indonesia
}

Received: 12 April 2019; Accepted: 21 May 2019; Published online: 31 May 2019

DOI: $10.21787 /$ jbp.11.2019.111-123

\begin{abstract}
This study was about the performance of researchers in the Ministry of Home Affairs' Research and Development Agency (R\& D Unit of the MoHA). This research was motivated by the suboptimal performance of researchers in developing policies in the Ministry of Home Affairs. The purpose of this study was to describe the performance of the researchers and their various efforts on research and development in the Ministry of Home Affairs and Regional Government. This study used Structural Equation Modeling (SEM). The results of this study showed that empowerment has a direct effect on innovation and improvement of the researcher's performance. This means that more empowerment will lead to an increase in the performance of MoHA and Regional Government researchers indicated by the increase in R \& D innovations produced by the researchers. The Organization Commitment had a direct effect on innovation and improvement of the researcher's performance. This means that a high level of commitment in the organization will lead to an increase in the performance of MoHA and the Regional Government researchers, through the increase in innovations. Innovations had a direct effect on the researcher's performance. This means that a high degree of innovations will lead to an increase in the researchers' performance. Together, the increased empowerment and organizational commitment directly influence the performance of researchers. This means that increasing empowerment and organizational commitment at the same time will improve the researchers' performance. The novelty factor from this study was the theoretical implication that this study strengthens the previous studies, that empowerment directly influenced innovation and enhanced the researchers' performance, the organizational commitment had a direct effect on researcher innovation and improved the researchers' performance, innovations directly influenced the researchers' performance, and that empowerment and the organizational commitment together have a direct effect on the performance of researchers.
\end{abstract}

Keywords: Empowerment, Organization Commitment, Innovations, Performance, Researcher.

\section{INTRODUCTION}

Law of the Republic of Indonesia Number 23 of 2014 on Local Government (Indonesian Government, 2014) has regulated the role of research and development and regional innovation. The research and development institution is further regulated in Government Regulation Number 18 Year 2016 on Regional Units (Indonesian Government, 2016). The operation of research and development was regulated in the Minister of Home Affairs Regulation Number 20 of 2011 on Research and Development
Guidelines in the Ministry of Home Affairs and Regional Governments as amended by Regulation of the Minister of Home Affairs Number 17 of 2016 on Guidelines for Research and Development in the Ministry of Home Affairs and Regional Government (Ministry of Home Affairs, 2016). While the implementation of regional innovation is further regulated in Government Regulation Number 38 Year 2017 on Regional Innovation (Indonesian Government, 2017).

The number of international publications from Indonesia in the period 1996 - 2013 has reached

\footnotetext{
* Corresponding Author

Phone : +62818 103923

Email : teguhnarutomo_im11s3@mahasiswa.unj.ac.id
} 
25,481 and is ranked 61 in the world from 239 countries. China ranked first in Asia and second in the world after the United States with 3,129,719 publications in the period of 1996 - 2013 (Sugriwa, 2014).

Cislowski \& Purwadi (2011) in their "Study of the Role of Indonesian Government Research Units ('Balitbang') in Bridging Research and Development Policy" stated that the main problem for Research and Development Agencies and Universities are the low quality of researchers, both from their Academic training and their professionalism.

While Nielsen (2010) in his study titled "Comparative Experiences of Middle Income Countries" compares several countries in managing the science sector. Indonesian researcher does not earn an adequate remuneration, and it does not support the research institutions on an ongoing basis. In contrast, Singapore research institutions pay decent salaries enabling the researchers to focus on their main areas of expertise. In Singapore, books are cheaper, online libraries and journals are more readily available.

Helmi conducted an empirical study on improving the capabilities of innovation in research organizations and public development through trust-building programs via knowledge sharing. This study explains that R \& D organizations are important for innovations because their research and experiments produce various knowledge, which would then be integrated to create new knowledge, products, and innovations (2012, p. 105).

A study by Chew \& Chan (2008) on the employees of several industrial sectors in Australia was conducted to understand the correlation or relationship between human resource management practices, organizational commitment, and innovation. Liu's study (2015) titled "The Review of Empowerment Leadership" studied the psychological leadership empowerment in the workplace that produces differences in empowering leadership under different cultural backgrounds from a cross-cultural cultural perspective. Berraies, Chaher, \& Yahia (2014) tested the impact of employee empowerment and trust in Tunisia with study titled "Employee Empowerment and Its Importance for Trust, Innovation and Organizational Performance"

The R\&D Unit of the Ministry of Home Affairs issued a statistical data outlining the researchers' problems in the Ministry of Home Affairs and Regional Governments. (1) In term of quantity, the total number of researchers is only 284, which is not adequate for the vast working area (542 autonomous regions plus the 11 components of the Ministry of Home Affairs). (2) In term of quality, in 2016, the researchers' educational backgrounds are merely bachelor's degrees and master's degrees. (3) There was no Researcher who had a Functional Position of Research Professor. (4) Empowerment of researchers in the form of technical training in one fiscal year was very minimal. (5) The commitment of the research organization tends to be lacking because the organization is still structurally oriented. (6) The prevailing regulation has not maximized the researcher's role as an actor of innovation. (Data Balitbang, 2016).

Based on the above description and the previous studies, the author conducts the study to understand the researchers' problems in the Ministry of Home Affairs and Regional Government. Therefore, the author chose the title: Empowerment of Researchers, Organizational Commitment and Innovation in Development of Researchers' Performance in the Ministry of Home Affairs and Regional Government.

The theoretical implication is that this study strengthens the previous study that showed that empowerment directly influences innovation and enhances the performance of researchers, organizational commitment has a direct effect on researcher innovation and improves researcher performance, innovation directly influences the performance of researchers, and that the empowerment and organizational commitment together have a direct effect on the performance of researchers. In addition, there are also practical implications, by empowering indicators with the highest value and reinforcing factors to improve the performance of researchers through empowerment, organizational commitment, and innovation.

\section{METHOD}

This study used an associative quantitative research method with a causal research design to identify a causal relationship between independent variables or exogenous latent variables, (variable $\mathrm{X}$ ) and dependent variables or latent endogenous variables (variable Y). Data collection used in the study was a survey with in-depth interviews using a sample from the total population researchers in the Ministry of Home Affairs and Regional Government. The sampling method employed was the probability sampling techniques through simple random sampling. The sample size was determined using a formula developed by Isaac and Michael in Sugiyono $(2008,158)$, that a minimum sample of 10 times of the variable studied is needed, which resulted in a sample size of 193 people. The collection of data was conducted using a questionnaire.

The variables used in this study consisted of (1) Empowerment, measured through The Condition 
of Work Effectiveness Questionnaire II (CWEQ II) using the Kanter theory in Havaei \& Dahinten (2017) and Laschinger (2012), and Psychological Empowerment Scale (PEC) developed by Colquitt, LePine, \& Wesson (2009), (2) Organizational Commitment measured with Organizational Commitment Scale (OCS) by Meyer and Allen in Ghosh \& R. (2014) (3) Innovation, measured through the Innovation Strategy (IS) developed by Terziovski (2002), and (4) Research Performance measured through Judgment Performance Evaluation by Bernardin (2007).

The interval measurement scale used a Likert Scale, which consists of 5 categories of answers for each statement, which were Strongly Disagree (SD) rated as 1, Disagree (D) rated as 2, Somewhat Agree (SA) rated as 3, Agree (A) rated as 4, and Strongly Agree (SA) rated as 5.

The analytical tool used in processing data to test hypotheses was The Structural Equation Modeling (SEM) operated through the AMOS (Analysis of Moment Structure) program. The AMOS causal model shows measurements and structural problems and is used to analyze and test the hypothesis model by Confirmation Factor Analysis and Regression Weight Analysis. According to Ferdinand in Jogiyanto (2011, p. 52), there are 6 (six) stages in using the Structural Equation Model which are Model Specifications, Free Parameter Estimates, Examination of Fit, Model Modifications, Interpretation and Communication, Replication and Validation.

Modification of the model was tested by testing the standardized residuals value generated by a cut off value of 2.58. A residual value of 5\% interpreted as statically significance and shows a substantial prediction error for a pair of indicators. This study was carried in 2016 and was held for one year.

\section{RESUlTS AND DisCuSSION}

This study aims to determine the direct effect of the indicators on latent variables, and the direct or indirect effects of exogenous latent variables on endogenous latent variables. Based on the results of the test of the parameter estimates and the goodness of fit SEM model, the results of the study can be interpreted as follows:

\section{A. Construct Reliability of Initial Structural Equation Model}

Testing the validity of the model indicators of the initial structural equation was carried out on the value of construct reliability by testing the following hypothesis:
H0: $\rho=0$ (the indicator variables did not reflect the latent variables)

$\mathrm{H}: \rho \neq 0$ (the indicator variables reflected the latent variables)

The condition of the test was: if the value of the factor loadings of the standardized estimates of the Structural Equation Model is greater than the critical value of 0.7 , then reject $\mathrm{HO}$ (the factor loadings reflects the latent variable). Table 1 shows that the factor loading values of the initial structural

Table 1.

Convergent Validity Test

\begin{tabular}{|c|c|c|c|}
\hline \multicolumn{2}{|l|}{ Description of Path } & Loading Factor & P-Value \\
\hline \multicolumn{4}{|c|}{ Empowerment } \\
\hline Empowerment & $--->\quad X_{11}$ & 0.84 & 0.000 \\
\hline Empowerment & $--->\quad X_{12}$ & 0.77 & 0.000 \\
\hline Empowerment & $--->\quad X_{13}$ & 0.84 & 0.000 \\
\hline Empowerment & $--->X_{14}$ & 0.84 & 0.000 \\
\hline Empowerment & $--->\quad X_{15}$ & 0.74 & 0.000 \\
\hline Empowerment & $--->\quad X_{16}$ & 0.90 & 0.000 \\
\hline Empowerment & $--->\quad X_{17}$ & 0.83 & 0.000 \\
\hline \multicolumn{4}{|c|}{ Organization Commitment } \\
\hline Organization Commitment & $--->X_{21}$ & 0.86 & 0.000 \\
\hline Organization Commitment & $--->x_{22}$ & 0.86 & 0.000 \\
\hline Organization Commitment & $-\cdots X_{23}$ & 0.82 & 0.000 \\
\hline \multicolumn{4}{|c|}{ Innovation } \\
\hline Innovation & $--->\quad Y_{11}$ & 0.87 & 0.000 \\
\hline Innovation & $--->\quad Y_{12}$ & 0.86 & 0.000 \\
\hline Innovation & $--->\quad Y_{13}$ & 0.87 & 0.000 \\
\hline \multicolumn{4}{|c|}{ Researcher's Commitment } \\
\hline Researcher's Commitment & $--->\quad Y_{11}$ & 0.79 & 0.000 \\
\hline Researcher's Commitment & $--->\quad Y_{12}$ & 0.79 & 0.000 \\
\hline Researcher's Commitment & $--->\quad Y_{13}$ & 0.86 & 0.000 \\
\hline Researcher's Commitment & $\cdots \quad Y_{14}$ & 0.77 & 0.000 \\
\hline Researcher's Commitment & $--->\quad Y_{15}$ & 0.81 & 0.000 \\
\hline Researcher's Commitment & $--->\quad Y_{16}$ & 0.88 & 0.000 \\
\hline
\end{tabular}


equation for all indicators are greater than 0.7, then $\mathrm{H} 0$ was rejected. Thus, it can be concluded that all indicators reflect the latent variables. The factor loading value and the P-Value also determine whether an indicator is valid.

\section{B. Construct Reliability of Initial Structural Equation Model}

The goodness of fit of the initial Structural Equation Model can be seen from the goodness of fit values listed in Table 2 . The Condition for testing the chi-square value was: if $X_{\text {count }}^{2}$ was small or < table then the model was feasible. If the $\operatorname{sig}>\alpha=0,05$ then the model is feasible. The model was also feasible if the RMSEA $\leq 0.08 \leq 0.08 \mathrm{GFI}$ and AGFI $\geq 0.90 \geq 0.90$ while TLI and CFI $\geq 0.95 \geq 0.95$.

Table 2.

The Goodness of Fit Early Model

\begin{tabular}{lccc}
\hline $\begin{array}{l}\text { The Goodness } \\
\text { of Fit Index }\end{array}$ & Cut off Value & Value of Count & Descriptions \\
\hline $\begin{array}{l}\text { X2 - Chi } \\
\text { Square }\end{array}$ & Small & $\begin{array}{c}248.61> \\
175.20\end{array}$ & Poor Fit \\
\hline $\begin{array}{l}\text { Significant } \\
\text { Probability }\end{array}$ & $>0.05$ & 0.000 & Poor Fit \\
\hline RMSEA & $>0.08$ & 0.061 & Good Fit \\
\hline GFI & $>0.90$ & 0.880 & Poor Fit \\
\hline AGFI & $>0.90$ & 0.843 & Poor Fit \\
\hline TLI & $>0.95$ & 0.966 & Good Fit \\
\hline CFI & $>0.95$ & 0.971 & Good Fit \\
\hline
\end{tabular}

\section{Modification of the Initial Structural Equation Model}

Modifications to the path diagram of the initial Structural Equation Model were carried out because the model was not feasible. Model modification was conducted by adding correlation lines from e1 to e2; e1 to e3; e9 to e12; e14 to e16; e16 to e17; and e16 to e19, based on the Modification Indices (MI) in Table 3.

The addition of path from e1 to e 2 linked the opportunity access to the information access. The addition of path from e1 to e3 linked the opportunity access to the resources. The addition of path from e9 to e12 linked the continuing commitment of researchers with incremental innovations of researchers. The path from e14 to e16 linked the quantity with the timeliness. The path from e14 to
Table 3.

Modification Indices in the Early Model

\begin{tabular}{|c|c|c|c|c|}
\hline & Path & & M.I. & Par Change \\
\hline e17 & $<-->$ & e20 & 7.589 &,- 087 \\
\hline e16 & $<-->$ & e19 & 12.899 &,- 318 \\
\hline e16 & $<-->$ & e17 & 24.690 & -.603 \\
\hline e14 & $<->$ & e18 & 5.435 & -.232 \\
\hline e14 & $<-->$ & e16 & 6.817 & -,192 \\
\hline e11 & <--> & e18 & 4.763 &,- 343 \\
\hline e11 & $<->$ & e12 & 4.124 & -.307 \\
\hline e10 & $<-->$ & e18 & 4.725 &,- 620 \\
\hline e9 & $<-->$ & e17 & 4.608 &,- 649 \\
\hline e9 & $<->$ & e12 & 11.567 & 1.004 \\
\hline e4 & $<-->$ & e21 & 4.946 & -,196 \\
\hline e4 & $<-->$ & e16 & 4.310 &,- 180 \\
\hline e3 & $<->$ & e16 & 5.560 & -.109 \\
\hline e2 & $<-->$ & e13 & 5.432 & -.308 \\
\hline e2 & $<-->$ & e6 & 4.987 &,- 314 \\
\hline e1 & $<-->$ & e3 & 24.323 & -,192 \\
\hline e1 & <--> & e2 & 5.050 & -.207 \\
\hline
\end{tabular}

e16 linked the timeliness with cost-effectiveness. The path from e16 to e19 linked the timeliness with the interpersonal impact.

\section{Construct Reliability of the Second Structural Equation Model}

Testing the validity of the model indicators of the second structural equation was carried out on the value of construct reliability through testing the following hypothesis:

H0: $\rho=0$

H1: $\rho \neq 0$

The condition of testing: if the factor loading value of the standardized estimates of the Structural Equation Model is greater than the critical value of 0.7 , then reject $\mathrm{HO}$ (the factor load value reflects the latent variable).

Testing of the validity of indicators of latent empowerment variables shows that all indicators 
Table 4.

Testing of Empowerment Indicators on the Second Structural Equation

\begin{tabular}{|c|c|c|c|c|}
\hline \multicolumn{3}{|c|}{ Description of Path } & \multirow[t]{2}{*}{ Loading Factor } & \multirow[t]{2}{*}{ P-Value } \\
\hline \multicolumn{3}{|r|}{ Empowerment } & & \\
\hline Empowerment & $--->$ & $\mathrm{X}_{11}$ (Opportunity) & 0.83 & 0.0 \\
\hline Empowerment & $--->$ & $\mathrm{X}_{12}$ (Information) & 0.78 & 0.0 \\
\hline Empowerment & $--->$ & $\mathrm{X}_{13}$ (Resources) & 0.82 & 0.0 \\
\hline Empowerment & $--->$ & $\mathrm{X}_{14}$ (Support) & 0.84 & 0.0 \\
\hline Empowerment & $--->$ & $\mathrm{X}_{15}$ (Formal Power) & 0.74 & 0.0 \\
\hline Empowerment & $--->$ & $\mathrm{X}_{16}$ (Informal Power) & 0.90 & 0.0 \\
\hline Empowerment & $--->$ & $\mathrm{X}_{17}$ (Impact) & 0.83 & 0.0 \\
\hline \multicolumn{5}{|c|}{ Organization Commitment } \\
\hline Organization Commitment & $--->$ & $\mathrm{X}_{21}$ (Effective) & 0.86 & 0.0 \\
\hline Organization Commitment & $--->$ & $\mathrm{X}_{22}$ (Continuous) & 0.86 & 0.0 \\
\hline Organization Commitment & $--->$ & $\mathrm{X}_{23}$ (Normative) & 0.82 & 0.0 \\
\hline \multicolumn{5}{|c|}{ Innovation } \\
\hline Innovation & $--->$ & $\mathrm{Y}_{11}$ (Radical) & 0.87 & 0.0 \\
\hline Innovation & $--->$ & $Y_{12}$ (Incremental) & 0.86 & 0.0 \\
\hline Innovation & $--->$ & $\mathrm{Y}_{13}$ (Transformative) & 0.87 & 0.0 \\
\hline \multicolumn{5}{|c|}{ Performance } \\
\hline Performance & $--->$ & $\mathrm{Y}_{21}$ (Quality) & 0.79 & 0.0 \\
\hline Performance & $--->$ & $Y_{22}$ (Quality) & 0.78 & 0.0 \\
\hline Performance & $--->$ & $Y_{23}$ (Timeliness) & 0.86 & 0.0 \\
\hline Performance & $--->$ & $Y_{24}$ (Cost Effectiveness) & 0.76 & 0.0 \\
\hline Performance & $--->$ & $Y_{25}$ (Supervision Needs) & 0.80 & 0.0 \\
\hline Performance & $--->$ & $\mathrm{Y}_{26}$ (Interpersonal Impact) & 0.87 & 0.0 \\
\hline
\end{tabular}

have a factor loading value of more than 0.7 . Validity testing using the $\mathrm{p}$-Value value shows that all the factor loading values are at $5 \%$, so it can be concluded that the X11, X12, X13, X14, X15, X16, and $x 17$ reflect latent variable of Empowerment.

Testing of the validity of indicators of latent variables of organization shows that all indicators have a factor loading value of more than 0.7 . Validity testing on the latent variable of Organization Commitment shows that the factor loading values are at $5 \%$, so it can be concluded that the X21, X22, and X23 reflect latent variable of Organization Commitment.

Testing of the validity of indicators of latent variables of researchers' innovations shows that all indicators have a factor loading value of more than 0.7. Validity testing on the latent variable of Researchers' Innovations shows that the factor loading values are at $5 \%$, so it can be concluded that the Y11, Y22, and Y13 reflect the latent variable of Researchers' Innovations.

Testing of the validity of indicators of latent 


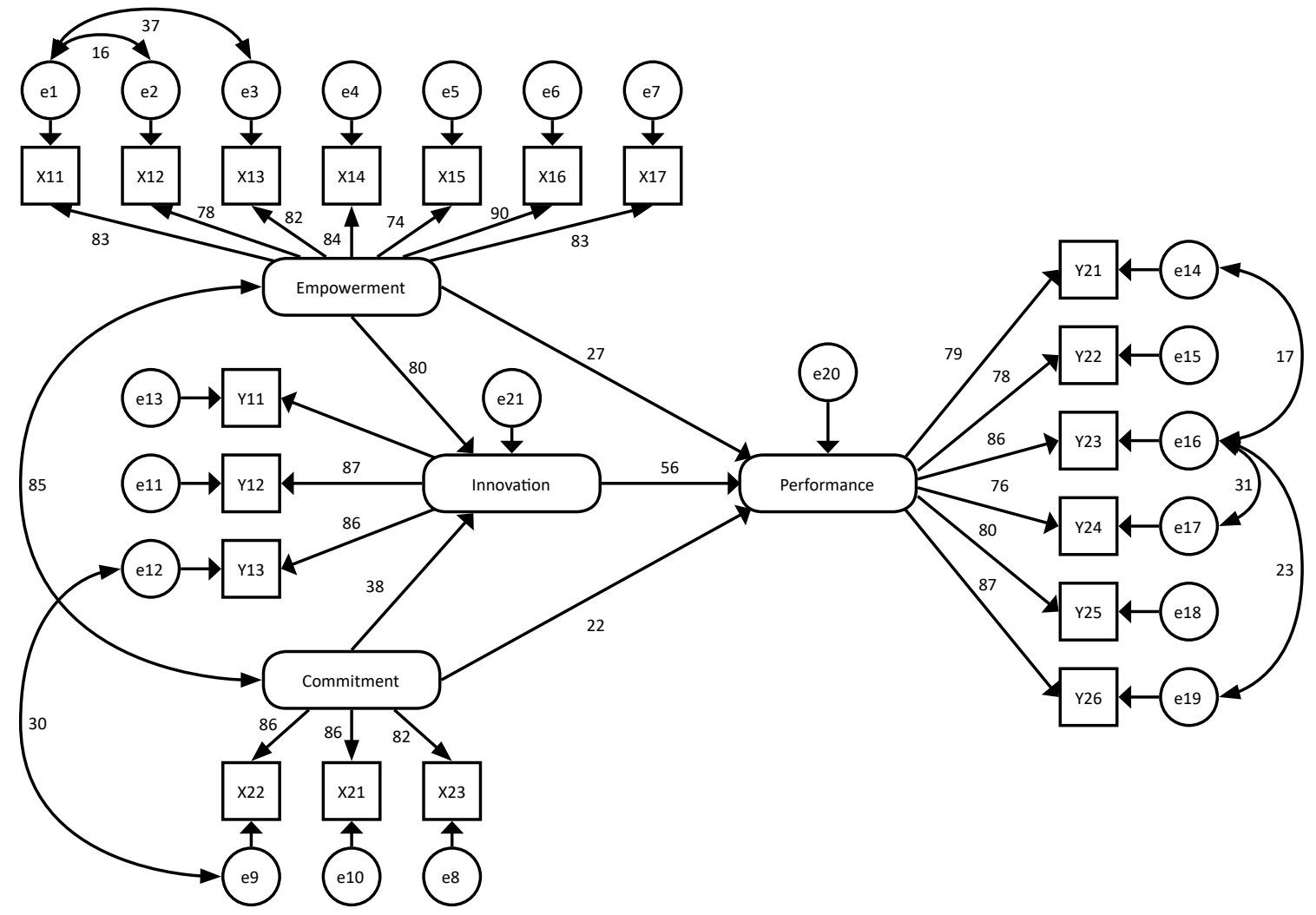

Figure 1. Reliability Construct of Path Diagram in the second Model

variables of researchers' innovations shows that all indicators have a factor loading value of more than 0.7 . Validity testing on the latent variable of Researchers' Performance shows that the factor loading values are at $5 \%$, so it can be concluded that the Y21, Y22, Y23, Y24, Y25, and Y26 reflect the latent variable of Researchers' Performance.

Based on the path diagram of the second structural equation model, the factor loading values of all indicators are greater than 0.7 , then $\mathrm{H} 0$ was rejected. This indicates that the indicator variable has high validity in reflecting its latent variable.

\section{E. Parameter Estimation and Testing of the Second Structural Equation Model}

Testing of the estimated coefficient of the indicator parameter for the second structural equation model was conducted by testing the following hypothesis:

H0: $\beta=0$

$\mathrm{H} 1$ : one value of $\beta$ is different.

The condition of test: If the sig $\leq \alpha=0,05$ then reject $\mathrm{HO}$ (the estimated coefficient is significant at the real level) $\alpha$. Table 5 shows that all Empowerment indicators have significant values of smaller $\alpha$ than 0.05 , then $\mathrm{H} 0$ was rejected. Thus, it can be concluded that indicators of opportunity, information, resources, superiors' support, formal power, informal power, and impact directly have a significant effect on the empowerment of researchers at the real level of $5 \%$.

The Effective, Continuous and Normative indicators have significant values of smaller $\alpha$ than 0.05 , then $\mathrm{HO}$ was rejected. This means that Affective, Continuous and Normative indicators have a direct effect on organizational commitment and are evident at the 5\% real level.

The Radical, Incremental and Integration indicators have significant values of smaller $\alpha$ than 0.05 , then $\mathrm{H} 0$ was rejected. This means that Radical, Incremental and Integration indicators have a direct effect on researchers' innovations at the $5 \%$ real level.

All Performance indicators have significant values of smaller $\alpha$ than 0.05 , then $\mathrm{H} 0$ was rejected. This means that the quality of performance, quantity of performance, timeliness, cost-effectiveness, supervision needs, and interpersonal impacts have a direct influence on the performance of researchers at a real level of $5 \%$.

The parameter of the latent variable of empowerment to innovation is 1.03 with $p$-value $0.000<\alpha 0.05$, then $\mathrm{H} 0$ was rejected. This means that Empowerment has a direct effect on Researchers' 
Table 5.

Estimation and Testing of Parameters in the Second Model

\begin{tabular}{|c|c|c|c|c|c|}
\hline \multicolumn{2}{|c|}{ Path Variables } & \multirow{2}{*}{$\begin{array}{r}\text { Estimate } \\
1.030\end{array}$} & \multirow{2}{*}{$\begin{array}{l}\text { S.E. } \\
-.162\end{array}$} & \multirow{2}{*}{$\begin{array}{l}\text { C.R. } \\
6.345\end{array}$} & \multirow{2}{*}{$\begin{array}{c}\mathbf{P} \\
0.000\end{array}$} \\
\hline Innovation & Empowerment & & & & \\
\hline Innovation & Commitment & -.296 & -.073 & 4.080 & 0.000 \\
\hline Performance & Empowerment & -.241 & -.072 & 3.374 & 0.000 \\
\hline Performance & Innovation & -.289 & -.056 & 5.196 & 0.000 \\
\hline Performance & Commitment & -.089 & -.025 & 3.515 & 0.000 \\
\hline $\mathrm{X} 11$ & Empowerment & 1.000 & & & 0.000 \\
\hline $\mathrm{X} 12$ & Empowerment & 1.150 & -.097 & 11.898 & 0.000 \\
\hline $\mathrm{X} 13$ & Empowerment & -.596 & -.034 & 17.566 & 0.000 \\
\hline X14 & Empowerment & 1.167 & -.081 & 14.477 & 0.000 \\
\hline $\mathrm{X} 15$ & Empowerment & -.916 & -.078 & 11.815 & 0.000 \\
\hline $\mathrm{X} 16$ & Empowerment & 2.033 & -.126 & 16.179 & 0.000 \\
\hline $\mathrm{X} 17$ & Empowerment & 1.833 & -.131 & 14.016 & 0.000 \\
\hline $\mathrm{X} 23$ & Commitment & 1.000 & & & 0.000 \\
\hline $\mathrm{X} 21$ & Commitment & 1.289 & -.089 & 14.436 & 0.000 \\
\hline$x 22$ & Commitment & 1.396 & -.096 & 14.470 & 0.000 \\
\hline Y12 & Innovation & 1.000 & & & 0.000 \\
\hline Y11 & Innovation & -.959 & -.058 & 16.493 & 0.000 \\
\hline Y13 & Innovation & 1.027 & -.062 & 16.615 & 0.000 \\
\hline Y21 & Performance & 1.000 & & & 0.000 \\
\hline Y22 & Performance & 1.114 & -.088 & 12.603 & 0.000 \\
\hline Y23 & Performance & 1.568 & -.099 & 15.764 & 0.000 \\
\hline Y24 & Performance & 1.506 & -.123 & 12.287 & 0.000 \\
\hline Y25 & Performance & 1.734 & -.132 & 13.187 & 0.000 \\
\hline Y26 & Performance & 1.682 & -.113 & 14.851 & 0.000 \\
\hline
\end{tabular}

Innovations and are evident at the 5\% real level.

The parameter of Organization Commitment to Innovation is 0.30 with p-value $0.000<\alpha 0.05$, then $\mathrm{H0}$ was rejected. This means that Organization Commitment has a direct effect on Researchers' Innovations and are evident at the 5\% real level.

The Estimated Coefficient of Empowerment to Performance is 0.24 with $p$-value $0.000<\alpha 0.05$, then $\mathrm{HO}$ was rejected. This means that Empowerment has a direct effect on Researchers' Performance and are evident at the $5 \%$ real level.

The Estimated Coefficient of Organization Commitment to Researchers' Performance is 0.09 with p-value $0.000<\alpha 0.05$, then $\mathrm{H} 0$ was rejected. This means that Organization Commitment has a direct effect on Researchers' Innovations and are evident at the $5 \%$ real level.

The Estimated Coefficient of Innovation to Researchers' Performance is 0.29 with p-value $0.000<\alpha 0.05$, then $\mathrm{H} 0$ was rejected. This means that Researchers' Innovations have a direct effect on Researchers' Performance and are evident at the $5 \%$ real level.

Table 5 also shows the most influential indicators to the respective latent variables as shown in the estimated number. The most influential indicator for the Performance variable is the Supervisory Needs (Y25). The most influential indicator of the Innovation variable is Transformative nature (Y13). The most influential indicator for the Organization Commitment variable is Continuous Commitment (X22). The most influential indicator for the Empowerment variable is the Informal Power (X16).

\section{F. Construct Reliability of the Second Structural Equation Model}

The goodness of fit of the second Structural Equation Model can be seen from the goodness of fit values listed in Table 6. The Condition for testing the chi-square value was: if X2count was small or $<$ table then the model was feasible. If the sig $>\alpha$ $=0.05$, then the model is feasible. The model also feasible if the

Table 6.

The Goodness of Fit Model

The Second Structural Equation Model

\begin{tabular}{lccc}
\hline $\begin{array}{l}\text { The Goodness } \\
\text { of Fit Index }\end{array}$ & Cut off Value & Value of Count & Descriptions \\
\hline $\begin{array}{l}\text { X2-Chi- } \\
\text { Square }\end{array}$ & Small & $\begin{array}{c}162.12< \\
168.61\end{array}$ & Good Fit \\
\hline $\begin{array}{l}\text { Significant } \\
\text { Probability }\end{array}$ & $>0.05$ & 0.097 & Good Fit \\
\hline RMSEA & $<0.08$ & 0.029 & Good Fit \\
\hline GFI & $>0.90$ & 0.919 & Good Fit \\
\hline AGFI & $>0.90$ & 0.890 & Poor Fit \\
\hline TLI & $>0.95$ & 0.992 & Good Fit \\
\hline CFI & $>0.95$ & 0.994 & Good Fit \\
\hline
\end{tabular}


RMSEA $\leq 0,08$, GFI and AGFI $\geq 0,90$ while TLI dan $\mathrm{CFI} \geq 0,95$.

The TLI dan CFI values of 0.992 and 0.994 are higher than the critical value of 0.95 . This means that all measures of the goodness of the model have met the critical value, except the AGFI criteria. Thus, it can be concluded that the second Structural Equation Model is simultaneously feasible to use.

\section{G. Analysis between Variables}

\section{1) The Influence of Empowerment to Researcher's Innovation in the Ministry of Home Affairs and Regional Government}

The influence of empowerment on innovation was based on the opinion of McShane \& Von Glinow (2013), which states that someone who is empowered tends to experiment, find new solutions to situations that challenge and produce creative/ innovative outcomes. Subramaniam (2007) found that the organizational climate that supports innovation strongly increases the level of innovative behavior of the engineers and scientists from a Research \& Development Department in a large company in America.

The estimated coefficient of the latent variable of Empowerment to Researchers' innovation is 1.030 and is evident at the 5\% real level. This showed that empowerment has a direct effect on the researchers' innovation. It can be interpreted that if empowerment rises by one unit and organizational commitment remain, it will increase the innovation of researchers in the Ministry of Home Affairs and Regional Government by 1.030. On the other hand, the increase in the latent variable of Empowerment can be determined by these indicators: opportunity (X11), information (X12), support (X14), formal power (X15), informal power (X16) and impact (X17).

The coefficient values of the seven indicators: opportunity (X11), information (X12), resources (X13), support (X14), formal power (X15), informal power (X16) and psychological impact (X17) are respectively: $1,000,1,150,0.596,1.167,0.916,2.033$ and 1.833 and are at the 5\% real level. This means that opportunity, information, resources, support, formal power, informal power, and psychological impact directly influence the empowerment of researchers. If the opportunity indicator rises by one unit and the others stays, then the researchers' empowerment will increase by 1,000. Every increase in the value of information by one unit will increase the researchers' empowerment by 1,150. Every increase in the value of resources by one unit will increase the researchers' empowerment by 0,596 . Every increase in the value of support by one unit will increase the researchers' empowerment by 1,167 . If the formal power increases by one unit, while the others remain the same, the researchers' empowerment will increase by 0,916 . If the informal power increases by one unit, while others remain the same, the researchers' empowerment will increase by 2,033 . Every increase in the value of psychological impact by one unit will increase the researchers' empowerment by 1,833 . These prove that empowerment influences the innovation of the R\&D.

The result of this analysis supported the previous study by Alkhodary (2016) titled "The Relationship between Employees' Empowerment and Innovative Work Behavior." Also study by Ertürk (2012) titled "Linking Psychological Empowerment to Innovation Capability: Investigating the Moderating Effect of Supervisory Trust."

\section{2) The Influence of Organization Commitment to Researcher's Innovation in the Ministry of Home Affairs and Regional Government}

The impact of an organization's commitment to Innovation is described by Kang (2006) as "A commitment-oriented Human Resource Management system may cultivate innovation through creating a cohesive internal environment in which employees trust and share knowledge with each other." Li \& Zheng (2014) stated, "With the rapid development of knowledge economy and the constantly updating of science and technology, almost all organizations have to face with an uncertain dynamic environment which brings enormous risks and competitive pressures. In order to gain competitive advantage, organizations must rely on employees to innovate in processes, methods, and operations."

The estimated coefficient of the latent variable of Organization Commitment to Researchers' innovation is 0.296 and is evident at the $5 \%$ real level. This showed that empowerment has a direct effect on the latent variable of researchers' innovation. It can be interpreted that if Organization Commitment rises by one unit and organizational commitment remain, it will increase the innovation of researchers in the Ministry of Home Affairs and Regional Government by 0.296. Indicators that significantly influence the latent variable of organizational commitment are effective (X21), sustainable (X22) and normative (X23) indicators.

The coefficients of affective (X21), continuity (X22) and normative (X23) are 1,289, 1,396 and 1,000 respectively and are real at the $5 \%$ level, this means that indicators of affective commitment, 
ongoing commitment, and normative commitment directly influence commitment. organization. If the Affective indicator rises by one unit and the others stays, then the Organization Commitment will increase by 1,289 . If the Continuous indicator rises by one unit and the others stays, then the Organization Commitment will increase by 1,396. Every increase of the value of the normative indicator by one unit will increase the Organization Commitment by 1,000 . Indicator variables that influence researchers' innovations are radical (Y11), incremental (Y12) and integration (Y13) indicators.

The result of this analysis supported the previous study by Martínez Serna, Vega Martínez, \& Eternod Domenech (2018) titled "La influencia del compromiso organizacional y orientación al aprendizaje sobre la innovación en las PYMES." Tarigan's study (2018) titled "The Impact of Organization Commitment to Process and Product Innovation in Improving Operational Performance."

\section{3) The Influence of Researchers' Innovations to Researcher's Performance in the Ministry of Home Affairs and Regional Government}

The impact of innovation on performance is described by Mahmutaj (2014) that "many studies have concluded that internal characteristics are crucial on achieving high organizational performance through innovation. It depends whether the organization develops a radical or incremental innovation, for which different strategies and structures are needed." OECD (2007) stated: "Moreover, innovation is important to help address global challenges, such as climate change and sustainable development. The innovative effort itself, including formal research and development, remains the sine qua non of growth. Studies suggest that investment in Research \& Development is associated with high rates of return. And investments in software have also contributed significantly to business performance and economic growth, accounting for as much as one-third of the contribution of ICT (information and communications technology) capital to GDP growth since 1995."

The estimation results of the researchers' innovations latent variable parameters to the performance of researchers is 0.289 and is real at the $5 \%$ level. This means that the researchers' latent variables directly influence the latent variables of the researchers' performance.

Indicators that significantly influence the latent variable of innovations are radical (Y11), incremental (Y12) and integration (Y13) indicators. The indicator coefficients of the Radical (Y11), Incremental (Y12) and Integration (Y13) indicators are $0.959,1.000$ and 1.027 respectively, and evident at the $5 \%$ real level, this means that the radical, incremental and integration indicators have a direct effect on researchers' innovations. If the opportunity indicator rises by one unit and the others stays, then the researchers' innovation will increase by 0,959. Every increase in the value of the incremental indicator by one unit will increase the researchers' innovation by 1,000 . Every increase in the value of integration by one unit will increase the researchers' innovation by 1,027 .

Regulations, such as Government Regulation Number 38 of 2017 on Regional Innovation and Minister of Home Affairs Regulation Number 17 of 2016 on the Guidelines for Research and Development in the Ministry of Home Affairs and Regional Governments, are the legal umbrella for the implementation of innovations for researchers in the Ministry of Home Affairs and Regional Government. This proves that the innovations carried out by researchers have a direct effect on the performance of researchers.

This result supported the previous studies published in international journals by Samad (2012) titled "The Influence of Innovation and Transformational Leadership on Organizational Performance" and Salim \& Sulaiman (2011) article titled "Organizational Learning, Innovation and Performance: A Study of Malaysian Small and Medium Sized Enterprises."

\section{4) The Influence of Empowerment to Researcher's Performance in the Ministry of Home Affairs and Regional Government \\ Mustafa \& Bon (2012) stated that "Employee} empowerment is a key Total Quality Management practice that managers count on to increase the success of TQM implementation. That is because Total Quality Management emphasizes the culture of involving all employees in the process and contributing to the work performance development." Kariuki \& Kiambati (2017) stated, "Employee empowerment (training and development, autonomy, involvement in decision making, access to information, management support) had a positive and significant influence on financial (revenue growth) and non-financial performance."

The estimation results of the latent variable of Empowerment to the performance of researchers is 0.241 and is evident at the $5 \%$ real level. This means that the researchers' latent variables of empowerment directly influence the latent variables of the researchers' performance. It can be interpreted that if Empowerment rises by one unit and the others remain, it will increase the researchers' performance in the Ministry of Home 
Affairs and Regional Government by 0.241 . Some indicator variables that have a significant effect on latent variables of Empowerment are an opportunity (X11), information (X12), resources (X13), support (X14), formal power (X15), informal power (X16) and impact (X17). The interpretation of the estimation parameters coefficient of empowerment indicator variable as in the previous discussion.

In addition, the indicator variables that significantly influence the latent variables of researchers' performance which reflect the latent variable of performance are quantity (Y21), quality (Y22), knowledge (Y23), Cooperation (Y24), reliability (Y25) and personal quality (Y26). The coefficients of each indicator are 1,000, 1,114, 1,568, $1,506,1,734$ and 1,682 respectively, as well evident at the $5 \%$ real level. This means that the quantity, quality, knowledge, cooperation, reliability, and personal quality directly influence the researchers' performance. If the quantity indicator rises by one unit and the others stays, then the researchers' performance will increase by 1,000 . If the quality indicator rises by one unit and the others stays, then the researchers' performance will increase by 1,114. If the knowledge indicator rises by one unit and the others stays, then the researchers' performance will increase by 1,568 . If the cooperation indicator rises by one unit and the others stays, then the researchers' performance will increase by 1,506 . If the reliability indicator rises by one unit and the others stays, then the researchers' performance will increase by 1,734 . Every increase in the value of the personal quality indicator by one unit will increase the researchers' performance by 1,682 .

The result of this analysis supported the previous study by Raquib, Anantharaman, Cyril Eze, \& Wahid Murad (2009) titled "Empowerment Practices and Performance in Malaysia - An Empirical Study." A study by Drake, Wong, \& Salter (2007) titled "Empowerment, Motivation, and Performance: Examining the Impact of Feedback and Incentives on Nonmanagement Employees."

\section{5) The Influence of Organization Commitment to Researcher's Performance in the Ministry of Home Affairs and Regional Government}

The impact of Organization Commitment to Performance described by AZ (2017) as "Employee performance is a mutual perception, ability, and effort for tasks. Organizational objectives can be achieved due to good performance. Although, more efforts are required for enhancement of organizational performance. Organizational commitment improves organizational competitiveness and employee's performance." The impact of the organization commitment to performance is enforced by Kessler (2013, p. 526) which stated "Organizational commitment has been shown to be a key antecedent of other important attitudes and behaviors, including those related to performance and turn over." With this process, the members of the organization express their concern for the organization, the success, and the subsequent welfare of the organization, and is the embodiment of their performance.

The coefficient of the latent variable of organizational commitment is 0.089 and is evident at the $5 \%$ real level. this means that the latent variable of organizational commitment directly influences the latent variables of the performance of the researcher. It can be interpreted that if Organization Commitment rises by one unit and the others remain, it will increase the researchers' performance in the Ministry of Home Affairs and Regional Government by 0.089. Increase of the latent variable of organizational commitment is influenced by affective (X21), sustainable (X22) and normative (X23) indicators. The interpretation of each indicator coefficient from the latent variable of organizational commitment is the same as in the previous discussion. The influence of organizational commitment consists of affective commitment with confidence in organizational values, ongoing commitment to the position and the related economic value, responsible normative commitment, and maintaining membership in the organization to the researchers' performance. Overall, organization commitment indicators (affective, continuous, and normative indicators) influenced the performance of the researchers.

The result of this analysis supported the previous study by Nazir \& Islam (2017) titled "Enhancing organizational commitment and employee performance through employee engagement." And also by Irefin \& Mechanic (2014) titled "Effect of Employee Commitment on Organizational Performance in Coca Cola Nigeria Limited Maiduguri, Borno State 1."

\section{Conclusion}

Based on the results of hypotheses testing and discussion, the study found: (1) Empowerment has a direct and significant effect on the innovation of researchers. This means that a high level of empowerment will lead to an increase of the researchers' performance in the Ministry of Home Affairs and Regional Government; (2) The OrganizationCommitmenthasadirectandsignificant influence on the researchers' innovations. This means that a high level of Organization Commitment will lead to an increase of the researchers' 
innovations in the Ministry of Home Affairs and Regional Government; (3) The researchers' innovation has a direct and significant influence on the researchers' performance. This means that the increase of researchers' innovations will lead to an increase of the researchers' performance in the Ministry of Home Affairs and Regional Government; (4) The Empowerment has a direct and significant influence on the researchers' performance. This means that a high level of empowerment will lead to an increase of the researchers' performance in the Ministry of Home Affairs and Regional Government; (5) The Organization Commitment has a direct and significant influence on the researchers' performance. This means that the increase of organization commitment will lead to an increase in the performance of researchers in the Ministry of Home Affairs and Regional Government.

This hypothesis testing proves that there was a direct influence between empowerment and innovation. This study reinforces the previous studies which state that empowerment has a significant effect on innovation.

This hypothesis testing proves that there was a direct influence between organization commitment and innovation. This study reinforces the previous studies which state that organizational commitment has a significant effect on innovation.

This hypothesis testing proves that there was a direct influence between innovation and performance. This study reinforces the previous studies which state that innovation has a significant effect on performance.

This hypothesis testing proves that there was a direct influence between empowerment and performance. This study reinforces the previous studies which state that empowerment has a significant effect on performance.

This hypothesis testing proves that there was a direct influence between organization commitment and performance. This study reinforces the previous studies which state that organizational commitment has a significant effect on performance.

Based on the results and findings of the study, some suggestions to improve the performance of researchers within the Ministry of Home Affairs and Regional Government are as follows: It is suggested to the Ministry of Home Affairs and Regional Government to improve the researchers' performance it is necessary to pay attention to the empowerment indicators as follows: (1) opportunity indicators; (2) information indicators; (3) support indicators; (4) formal indicators; (5) informal indicators; and (6) impact indicators It is suggested to the Ministry of Home Affairs and Regional Government to improve the researchers' performance it is necessary to pay attention to the Organization Commitments as follows: (1) affective indicators; (2) sustainable indicators; and (3) normative indicators. There are also the needs to have a driving force to improve the performance by applying these innovation indicators: (1) incremental innovation; (2) radical innovation and (3) integration innovation.

\section{ACKNOWLEDGMENT}

The author would like to thank Prof Dr. Muchlis R. Luddin as the Promoter and Prof. Dr. Thomas Suyatno as the Co-Promoter, Prof Dr. Hamidah as the Head of the Study Program of Management, Prof. Dr. Ilza Mayuni, MA, as the temporary Director of the Post Graduate Study of Universitas Negeri Jakarta Intan Ahmad, Ph. D as the temporary Rector of Universitas Negeri Jakarta. The entire Academic Community of the Universitas Jakarta and fellow postgraduate colleagues of the class of 2011. Head of R\&D Unit of the Ministry of Home Affairs, Head of Regional Innovation R\&D Center of the R\&D Unit of the Ministry of Home Affairs, All Heads of the Provincial R \& D Units, Researchers in the Ministry of Home Affairs and Regional Governments, who have provided input for this article.

\section{REFERENCES}

Alkhodary, D. (2016). The Relationship between Employees' Empowerment and Innovative Work Behavior. International Journal of Managerial Studies and Research (IJMSR), 4(2), 1-15.

AZ, H. (2017). Relationship between Organizational Commitment and Employee's Performance Evidence from Banking Sector of Lahore. Arabian Journal of Business and Management Review, 7(2), 1-7. https://doi.org/10.4172/22235833.1000304

Bernardin, H. J. (2007). Human Resource Management: An Experiential Approach (4th ed.). McGraw-Hill.

Berraies, S., Chaher, M., \& Yahia, K. Ben. (2014). Employee Empowerment and Its Importance for Trust, Innovation and Organizational Performance. Business Management and Strategy, 5(2), 82. https://doi.org/10.5296/bms. v5i2.6558

Chew, J., \& Chan, C. C. A. (2008). Human resource practices, organizational commitment and intention to stay. International Journal of Manpower, 29(6), 503-522. https://doi. org/10.1108/01437720810904194

Cislowski, H., \& Purwadi, A. (2011). Study of the Role of Indonesian Government Research Units ('Balitbang') in Bridging Research and Devel- 
opment Policy. In AusAID's Tertiary Education and Knowledge Sector Unit. Jakarta.

Colquitt, J., LePine, J., \& Wesson, M. (2009). Organizational Behavior: Improving Performance and Commitment in the Workplace. New York: McGraw-Hill Education.

Data Balitbang. (2016). Statistik Data Badan Penelitian dan Pengembangan Pusat dan Daerah. Jakarta.

Drake, A. R., Wong, J., \& Salter, S. B. (2007). Empowerment, Motivation, and Performance: Examining the Impact of Feedback and Incentives on Nonmanagement Employees. Behavioral Research in Accounting, 19(1), 71-89. https:// doi.org/10.2308/bria.2007.19.1.71

Ertürk, A. (2012). Linking Psychological Empowerment to Innovation Capability: Investigating the Moderating Effect of Supervisory Trust. International Journal of Business and Social Science, 3(14), 153-165.

Ghosh, S., \& R., S. D. (2014). A Literature Review on Organizational Commitment - A Comprehensive Summary. International Journal of Engineering Research and Applications, 4(12), 4-14.

Havaei, F., \& Dahinten, V. S. (2017). How Well Does the CWEQ II Measure Structural Empowerment? Findings from Applying Item Response Theory. Administrative Sciences, 7(2), 1-20. Retrieved from https://econpapers.repec.org/ article/gamjadmsc/v_3a7_3ay_3a2017_3ai_3a 2_3ap_3a15-_3ad_3a99386.htm

Helmi, R. L. (2012). Peningkatan Kapabilitas Inovasi di Orgaisasi Litbang Publik melalui Program Trust Building dalam Berbagi Pengetahuan. Universitas Indonesia.

Indonesian Government. Law of the Republic of Indonesia Number 23 of 2014 on Local Government. , Pub. L. No. 23 (2014).

Indonesian Government. Government Regulation of the Republic of Indonesia Number 18 Year 2016 on Regional Units. , Pub. L. No. 18 (2016).

Indonesian Government. Republic of Indonesia Government Regulation Number 38 Year 2017 on Regional Innovation. , Pub. L. No. 38 (2017).

Irefin, P., \& Mechanic, M. A. (2014). Effect of Employee Commitment on Organizational Performance in Coca Cola Nigeria Limited Maiduguri, Borno State 1. IOSR Journal Of Humanities And Social Science (IOSR-JHSS), 19(3), 33-41.

Jogiyanto. (2011). Konsep dan Aplikasi Structural Equation Modeling Berbasis Varian dalam Penelitian Bisnis. Yogyakarta: UPP STIM YKPN.

Kang, G. (2006). The hierarchical structure of service quality: integration of technical and functional quality. Managing Service Quality: An International Journal, 16(1), 37-50. https://doi. org/10.1108/09604520610639955

Kariuki, A., \& Kiambati, K. (2017). Empowerment, Organizational Commitment, Organization Citizenship Behavior and Firm Performance. Management Studies, 5(4), 290-300. https:// doi.org/10.17265/2328-2185/2017.04.003

Kessler, E. H. (2013). Encyclopedia of Management Theory. Los Angeles: SAGE Publications, Inc.

Laschinger, H. K. S. (2012). Conditions for Work Effectiveness Questionnaire I and II. Western University Canada.

Li, X., \& Zheng, Y. (2014). The Influential Factors of Employees' Innovative Behavior and the Management Advices. Journal of Service Science and Management, 07(06), 446-450. https://doi. org/10.4236/jssm.2014.76042

Liu, Y. (2015). The Review of Empowerment Leadership. Open Journal of Business and Management, 03(04), 476-482. https://doi.org/10.4236/ ojbm.2015.34049

Mahmutaj, L. R. (2014). The Impact of Innovation in SMEs Performance. Horizons: International Scientific Journal (Special Edtion), 12(2), 1-15.

Martínez Serna, M. D. C., Vega Martínez, J. E., \& Eternod Domenech, V. (2018). La influencia del compromiso organizacional y orientación al aprendizaje sobre la innovación en las PYMES. Contaduría y Administración, 63(3), 49. https:// doi.org/10.22201/fca.24488410e.2018.1411

McShane, S., \& Von Glinow, M. A. (2013). Organizational Behavior. New York: McGraw-Hill.

Ministry of Home Affairs. Regulation of the Minister of Home Affairs of the Republic of Indonesia Number 17 of 2016 on Guidelines for Research and Development in the Ministry of Home Affairs and Regional Government. , Pub. L. No. 17 (2016).

Mustafa, E., \& Bon, A. T. (2012). Role of Employee Empowerment in Organization Performance: A Review. Research Journal of Social Science \& Management (RJSSM), 2(6), 79-83. Retrieved from https://ssrn.com/abstract=2199748

Nazir, O., \& Islam, J. U. (2017). Enhancing organizational commitment and employee performance through employee engagement. South Asian Journal of Business Studies, 6(1), 98-114. https://doi.org/10.1108/SAJBS-04-2016-0036

Nielsen, G. (2010). Comparative Experiences of Middle Income Countries. Jakarta.

OECD. (2007). Innovation and Growth: Rationale for an Innovation Strategy.

Raquib, M. A., Anantharaman, R. N., Cyril Eze, U., \& Wahid Murad, M. (2009). Empowerment Practices and Performance in Malaysia - An Empirical Study. International Journal of Business 
and Management, 5(1), 123-149. https://doi. org/10.5539/ijbm.v5n1p123

Salim, I. M., \& Sulaiman, M. (2011). Organizational Learning, Innovation and Performance: A Study of Malaysian Small and Medium Sized Enterprises. International Journal of Business and Management, 6(12), 118-125. https://doi. org/10.5539/ijbm.v6n12p118

Samad, S. (2012). The Influence of Innovation and Transformational Leadership on Organizational Performance. Procedia - Social and Behavioral Sciences, 57, 486-493. https://doi. org/10.1016/j.sbspro.2012.09.1215

Subramaniam, I. D. (2007). Determinants of Innovative Behaviour in the Workplace: A Case Study of a Malaysian Public Sector Organisation. European Journal of Social Sciences, 5(3), 96-108.

Sugiyono. (2008). Metode Penelitian Administrasi (14th ed.). Bandung: CV Alfabeta.

Sugriwa, I. A. (2014, December 6). Publikasi Ilmiah RI
Peringkat ke-11 Asia. Retrieved from Nasional. sindo news.com website: https://nasional.sindonews.com/read/933704/144/publikasi-ilmiah-ri-peringkat-ke-11-asia-1417791576

Tarigan, Z. J. H. (2018). The Impact of Organization Commitment to Process and Product Innovation in Improving Operational Performance. International Journal of Business and Society, 19(2), 335-346. Retrieved from http://www. ijbs.unimas.my/index.php/content-abstract/ current-issue/476-the-impact-of-organization-commitment-to-process-and-product-innovation-in-improving-operational-performance

Terziovski, M. (2002). Achieving performance excellence through an integrated strategy of radical innovation and continuous improvement. Measuring Business Excellence, 6(2), 5-14. https://doi. org/10.1108/13683040210431419 